\title{
First peak insulin release after intravenous glucose and arginine is maintained for up to 3 years after segmental pancreas transplantation
}

\author{
A. Secchi ${ }^{1}$, S. Martinenghi ${ }^{1}$, R. Caldara ${ }^{1}$, E. La Rocca ${ }^{1}$, V. Di Carlo ${ }^{2}$ and G. Pozza ${ }^{1}$ \\ Departments of ${ }^{1}$ Internal Medicine and ${ }^{2}$ Surgery, Istituto Scientifico San Raffaele, Milan, Italy
}

Summary. In this study we have investigated blood glucose and serum free insulin response to glucose and to arginine orally or intravenously, 3 months and 3 years after a successful segmental, neoprene-injected, pancreas transplantation.

Serum insulin responses to different secretagogues were normal 3 months after transplantation; they remained normal up to 3 years after transplantation.

Key Words: Pancreas transplantation - intravenous glucose tolerance test - oral glucose tolerance test arginine test.

\section{Introduction}

Several investigations have shown that a transplanted pancreas is able to lead to insulin-independence and to restore near-normal glucose tolerance up to 6 years after transplantation (Pozza 1983, Pozza 1985, Sutherland 1981, Secchi 1990). Insulin resistence, present before transplantation, is reduced, through improved tissue glucose disposal (Luzi 1990). Hepatic glucose production is also reduced (Luzi 1990) by insulin infusion. These studies have shown that the transplanted Beta cell correctly responds to different insulinogenic stimuli, such as arginine and glucose, both i.v. and orally (Pozza 1983, Secchi 1985). Whether this capacity is maintained over time has never been evaluated.

The aim of our study was to evaluate the response to arginine and glucose (orally or i.v.) of patients submitted to kidney and pancreas transplantation up to 3 years post-transplant.

\begin{abstract}
Subjects and Methods
Patients. 14 Type 1 (insulin-dependent) diabetic uraemic patients , submitted to a segmental, neoprene-injected pancreas (Dubernard 1978) and kidney transplantation, were investigated up to 3 years after surgery.
\end{abstract}

Immunosuppression. was based on anti-lymphocyte globulin (ALG) (10 days), cyclosporin (7-5 mg.kg-1.day ${ }^{-1}$ orally, tapered), azathioprine ( $2 \mathrm{mg} \cdot \mathrm{kg}^{-1}$.day ${ }^{-1}$, tapered), prednisone ( $1 \mathrm{mg} \cdot \mathrm{kg}^{-1}$.day ${ }^{-1}$, tapered).

Metabolic investigations. the following tests were performed 3 months after transplantation and at annual intervals, for 3 years in all patients:

- oral glucose tolerancetest (OGTT, $75 \mathrm{~g}$ ): blood samples for glucose and insulin were taken at $0,30,60,90,120,180 \mathrm{~min}$;

- i.v. glucose tolerance test (IVGTT): $0.5 \mathrm{~g} / \mathrm{kg}$ body weight of glucose were infused for $1 \mathrm{~min}$; blood samples for glucose and insulin were taken at $1,3,5,10,20,30,40,50,60 \mathrm{~min}$;

- arginine test: $30 \mathrm{~g}$ of arginine were infused over $30 \mathrm{~min}$; blood samples for insulin and glucagon were taken at $0,5,10,20,30,45$, $60,120 \mathrm{~min}$.

Assays. blood glucose levels were evaluated with a glucose analyser (Heding 1972)

Statistical analysis. values in figures are shown as mean \pm SEM. $\mathrm{p}=$ paired Student $t$-test.

\section{Results}

Three months after transplantation the 14 patients studied showed an impaired glucose tolerance after oral glucose (Blood glucose at $120 \mathrm{~min}=180.4 \pm 15.4$ $\mathrm{mg} / \mathrm{dl})$. Serum free insulin reached the peak $(48.8 \pm 8.6$ $\mu \mathrm{U} / \mathrm{ml}$ ) at $120 \mathrm{~min}$ (Fig.1). i.v. glucose induced an early release of insulin, with a peak $(45.8 \pm 7.7$ $\mu \mathrm{U} / \mathrm{ml}$ ) at $3 \mathrm{~min}$ (Fig.2). Arginine infusion induced a biphasic insulin release (Fig.3). 


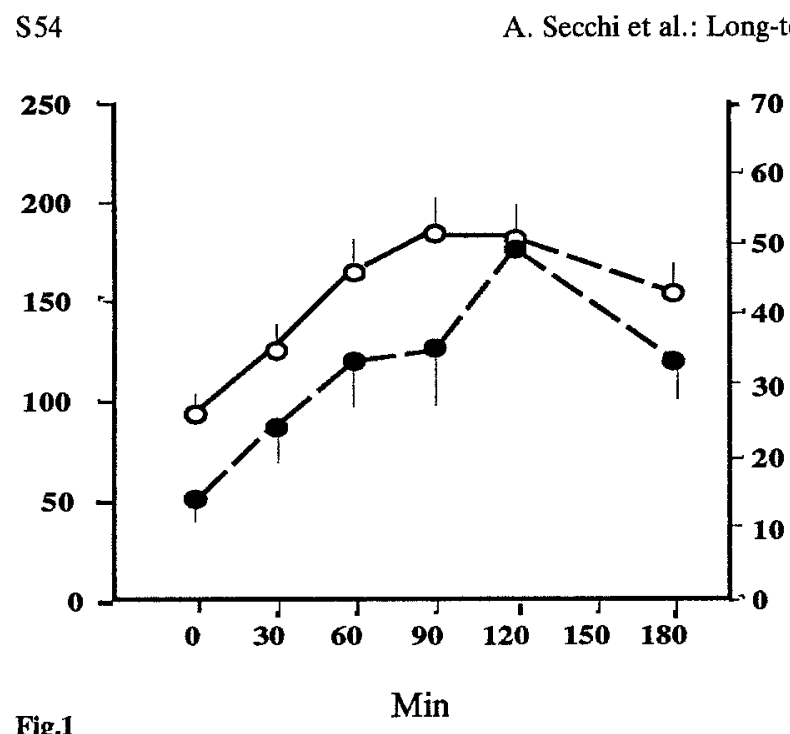

Blood glucose (mg/d) $\bigcirc$ and serum free insulin $O$ levels $(\mu \mathrm{U} / \mathrm{ml})$ after oral glucose $(75 \mathrm{~g}) 3$ months after segmental, neoprene injected, pancreas transplantation

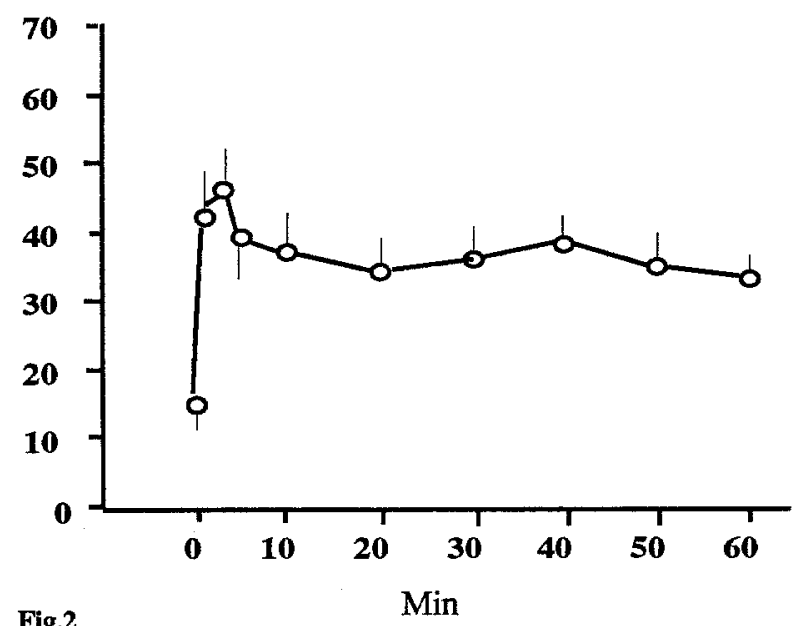

Ferum free insulin $(\mu \mathrm{U} / \mathrm{ml})$ response $(0.50 \mathrm{~g} / \mathrm{kg}$ body weight) in 14 patients 3 months after segmental, neoprene injected, pancreas transplantation

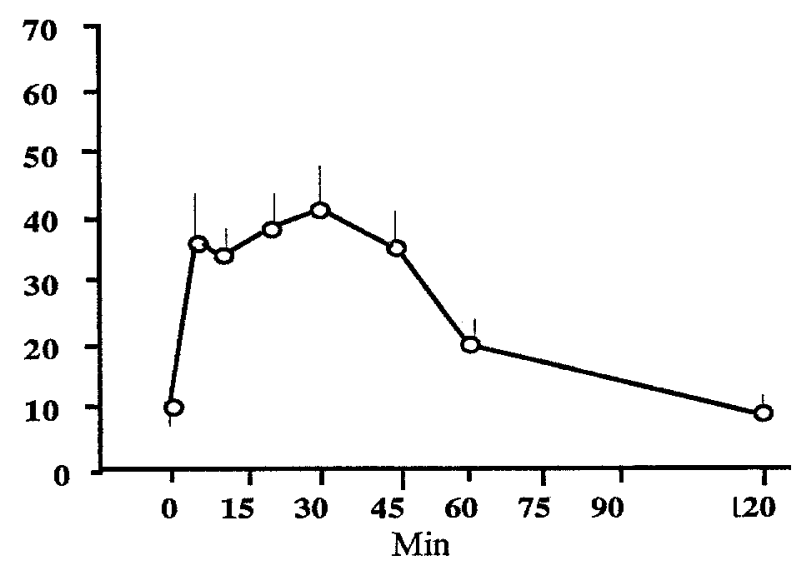

Fig.3

Senum free insulin levels $(\mu \mathrm{U} / \mathrm{ml})$ during arginine infusion (30 $\mathrm{g}$ over $30 \mathrm{~min}$ ) in 9 patients 3 months after segmental, neoprene injected, pancreas transplantation
The six patients 3 year follow-up produced the following results:

OGTT: blood glucose response to oral glucose 3 months after transplantation showed an impaired glucose tolerance $(\mathrm{BG}$ at $120 \mathrm{~min}=187.5 \pm 26.8$ $\mathrm{mg} / \mathrm{dl})$. Blood glucose response to oral glucose was normal 3 years after transplantation (BG at $120 \mathrm{~min}=$ $127.7 \pm 29.0 \mathrm{mg} / \mathrm{dl}$ ) (Fig.4). Serum free insulin levels were similar in the fasting state at 3 months and at 3 years after surgery $(15.5 \pm 7.2$ vs $12.9 \pm 2.0 \mu \mathrm{U} / \mathrm{ml})$. At 3 months insulin peak was achieved at $120 \mathrm{~min}$ $(58.3 \pm 18.2 \mu \mathrm{U} / \mathrm{ml})$, while at 3 years it was achieved earlier $(41.7 \pm 13.4 \mu \mathrm{U} / \mathrm{ml}$ at $30 \mathrm{~min})$ (Fig.5).

IVGTT: 3 months after transplantation i.v. glucose

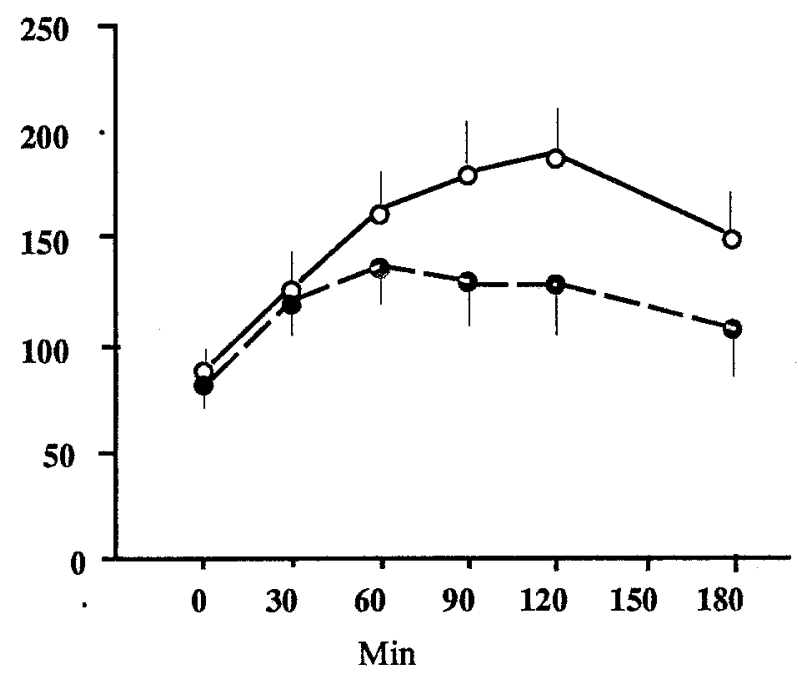

Fig.4

Blood glucose levels (mg/dl) after oral glucose $(75 \mathrm{~g} \mathrm{p.o.)} \mathrm{in} \mathrm{six}$ patients 3 months $\bigcirc$ and 3 years $\bigcirc$ after segmental, neoprene injected, pancreas transplantation $(\mathrm{p}=\mathrm{ns})$

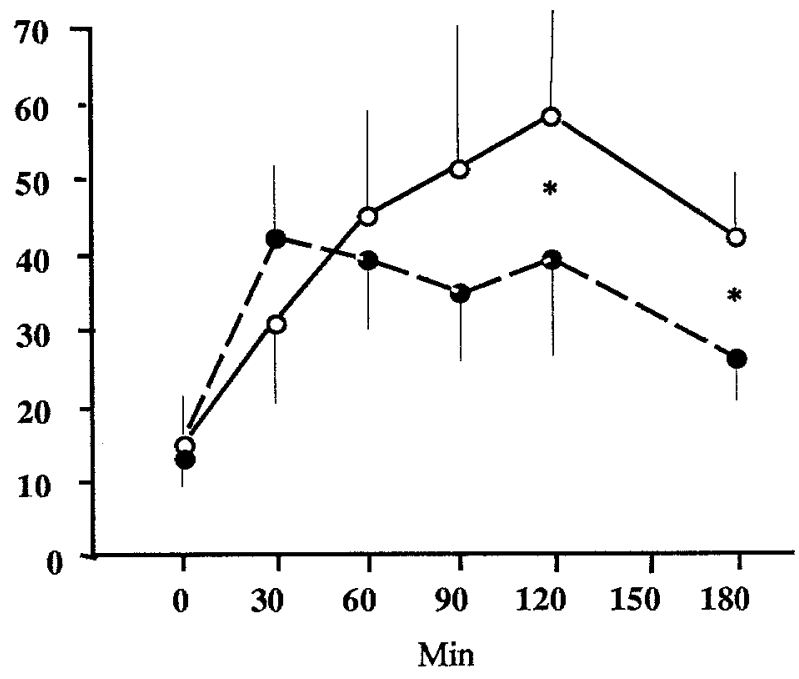

Fig.5

Serum free insulin levels $(\mu \mathrm{U} / \mathrm{ml})$ after oral glucose $(75 \mathrm{~g}$ p.o.) in six patients 3 months $\bigcirc$ and 3 years $\bigcirc$ after segmental, neoprene injected, pancreas transplantation $(* p<0.05)$ 
induced a rapid release of insulin, reaching the peak $(52.6 \pm 7.9 \mu \mathrm{U} / \mathrm{ml})$ at $1 \mathrm{~min}$; a second phase of insulin release was observed, with a peak $(45.1 \pm 6.3 \mu \mathrm{U} / \mathrm{ml})$ at $40 \mathrm{~min}$. A similar response to i.v. glucose was observed 3 years after transplantation, with a peak $(59.4 \pm 25.5 \mu \mathrm{U} / \mathrm{ml})$ at $1 \mathrm{~min}$ and a second phase of insulin release, with a peak $(36.0+7.7 \mu \mathrm{U} / \mathrm{ml})$ at 50 $\min$ (Fig.6).

Arginine infusion test: 3 months after transplantation

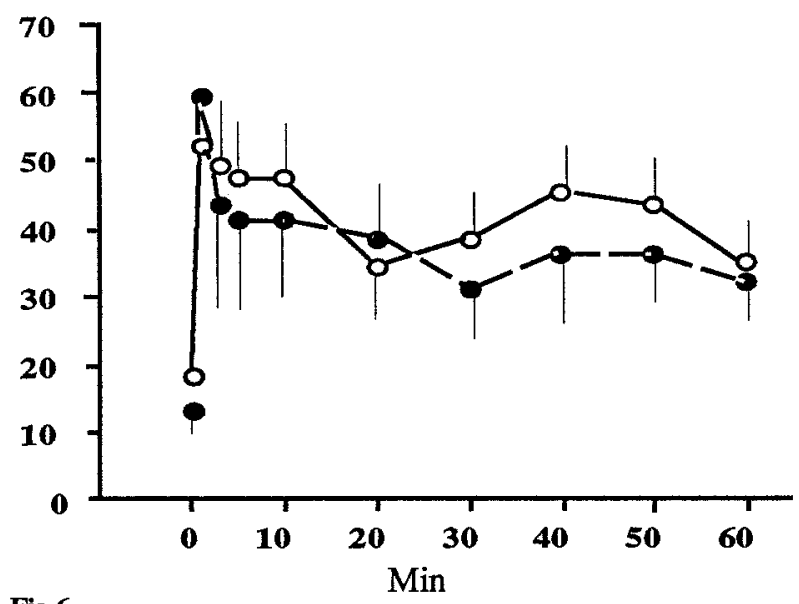

Fig.6

Serum free insulin $(\mu \mathrm{U} / \mathrm{ml})$ response to i.v. glucose $(0.5 / \mathrm{kg}$ body weight) in six patients 3 months $\bigcirc$ and 3 years $O$ after segmental, neoprene injected, pancreas transplantation

arginine infusion induced a biphasic insulin secretion, with 1st peak $(45.3 \pm 19.0 \mu \mathrm{U} / \mathrm{ml})$ at $5 \mathrm{~min}$, and 2nd peak $(45.9 \pm 14.7 \mu \mathrm{U} / \mathrm{ml})$ at $30 \mathrm{~min} .3$ years after transplantation a higher, although not significant, insulin release was induced by arginine (1st peak: 60.7 $\pm 9.1 \mu \mathrm{U} / \mathrm{ml}$ at $5 \mathrm{~min}, 2 \mathrm{nd}$ peak: $67.4 \pm 7.4 \mu \mathrm{U} / \mathrm{ml}$ at $20 \mathrm{~min}$ ) (Fig.7).

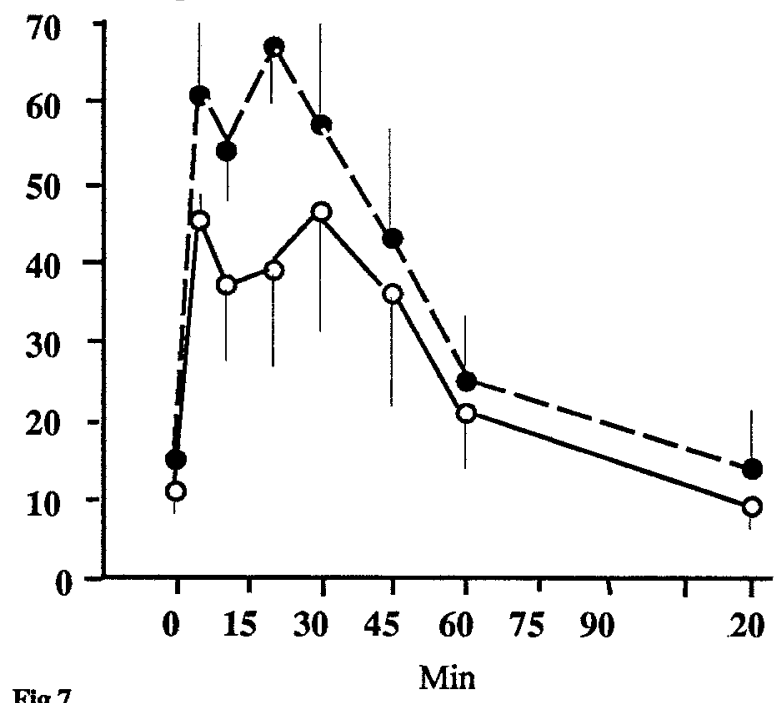

Fig.7

Serum free insulin $(\mu \mathrm{U} / \mathrm{ml})$ during arginine infusion $(30 \mathrm{~g}$ over 30 $\mathrm{min}$ ) in four patients 3 months $O$ and 3 years $O$ after segmental, neoprene injected, pancreas transplantation

\section{Discussion}

The aim of pancreas transplantation is not only to induce insulin-independence, but also to control or reverse the development of long-term degenerative complications of diabetes. The positive effects of metabolic control on degenerative complications is a long-time requiring process (Dahl-Jorgensen 1986). Complete studies on the long-term Beta-cell response to different secretagogues after pancreas transplantation are currently lacking. The aim of our study was to evaluate whether insulin release after glucose and arginine, which is normal immediately after transplantation, is maintained also in the long-term. The oral glucose tolerance test shows that an impaired glucose tolerance, present 3 months after transplantation, improves at 3 years. This improvement is not the consequence of an increased insulin release, which on the contrary appears reduced, but seems rather to be related to a reduction of insulin-resistance, as previously demonstrated (Luzi 1990). The Beta-cell response to i.v. glucose and to arginine is normal 3 months after transplantation and remains normal 3 years later. This study was performed in patients transplanted with a segmental, neoprene-injected pancreas: a sclerogenic effect of neoprene was supposed to affect also the endocrine part of the gland and to impair insulin release. This study shows that even a segmental pancreas previously injected with neoprene is able to maintain its secretory activity up to 3 years after transplantation. This response is maintained with different secretagogues, such as glucose and arginine, showing that the integrity of the Beta cell is completely preserved up to 3 years after transplantation. In conclusion, a segmental, neoprene-injected pancreas transplant maintains the capacity to respond to glucose and arginine up to 3 years after transplantation.

\section{References}

Dahl-Jorgensen $K$, Brinchmann-Hansen $O$, Hanssen KF, Ganes $T$, Kierful P, Smeland E, Sandvik L, Aagenaes O (1986) Effect of normoglycemia for two years on progression of early diabetic nephropathy and neuropathy: the Oslo study. Br Med J 293: 1195-1119

Dubernard JM, Traeger J, Neyra P, Touraine JL, Tranchant D, BlancBrunat N (1978) A new method of preparation of segmental pancreatic grafts for transplantation: trials in dogs and in man. Surgery 84: 633-639

Heding LG (1972) Determination of total senum insulin in insulintreated diabetic patients. Diabetologia 8: 260-266

Luzi L, Secchi A, Facchini F, Battezati A, Staudacher C, Spotti D, Castoldi R, Ferrari G, Di Carlo V, Pozza G (1990) Reduction of insulin resistance by combined kidney-pancreas transplantation in Type I (insulin-dependent) diabetic patients. Diabetologia 33: 1-8

Pozza G, Traeger J, Dubernard JM, Secchi A, Pontiroli A, Bosi E, Malik MC, Ruitton A, Blanc N (1983) Endocrine response of Type I diabetic patients following successful pancreas transplantation. Diabetologia 24: 244-248 
Pozza G, Bosi E, Secchi A, Piatti PM, Touraine JL, Gelet A, Pontiroli A, Dubemard JM, Traeger J, (1985) Metabolic control of Type I diabetes after pancreas transplantation.

Br Med J 291: 510-513

Secchi A, Dubernard JM, Melandri M, Lefrancois N, Martinenghi S, Martin X, Traeger J, Pozza G (1990) Long-term metabolic effects of segmental pancreas transplantation. Transpl Proc 24: 227-228

Secchi A, Pontiroli A, Bosi E, Piatti PM, Monti L, Traeger J, Dubernard JM, Gelet A, Pozza G (1985) Effect of different immunosuppressive treatments on the endocrine function of segmental neoprene-injected pancreatic allografts.

Transpl Proc 17: 136-140

Sutherland DER, Najarian JS, Greenberg BZ, Senske BJ, Anderson JE, Francis RS, Goetz S (1981) Hormonal and metabolic effects

of pancreatic endocrine graft. Ann Int Med 95: 537-541

Dr. A. Secchi

Dept. of Internal Medecine

Istituto Scientifico San Raffaele

via Olgettina 60

20132 Milan

Italy 